\title{
The Difficult Conversation: Facilitating Students' Professional Learning and Development
}

\author{
Yvonne Bakken*, Nina Carson, Modgun Ohm \\ Western Norway University of Applied Sciences, Bergen, Norway
}

Copyright $\mathrm{C} 2019$ by authors, all rights reserved. Authors agree that this article remains permanently open access under the terms of the Creative Commons Attribution License 4.0 International License

\begin{abstract}
This paper reports on student experiences with an interdisciplinary project entitled "The Difficult Conversation", the aim of which was to develop professional competences linked with parental cooperation in heterogeneous social contexts, ethical reflection, pedagogical tact, and judgment skills. Student experiences with the project were reconstructed by analyzing 43 sets of reflection notes developed by second-year students who participated in the project in February and November 2015, and in January and November 2016. The students argued strongly in favor of the value of "The Difficult Conversation" reporting that it linked theory with practice, permitted them to develop empathy for parents, and provided them with a better understanding of parents from different cultural backgrounds. The conclusions refer to creating conditions for this aspect of professional learning in kindergarten teacher education programs.
\end{abstract}

Keywords Kindergarten Teacher Education, Norway, Diverse Parents, Parental Collaboration, the Difficult Conversation, Professional Judgment

\section{Introduction}

Both European and Norwegian policy documents identify educational institutions as significant arenas for intercultural dialog and, thereby, the early facilitation of social coherence and integration [1, 2, 3]. Research confirms that kindergartens and schools can function as supportive agencies in establishing family life in new countries $[4,5]$ and it identifies teachers as significant agents $[6,7]$.

That creates particular expectations for kindergarten teachers that are often the first teachers met by the parents from minority backgrounds. As mobility and migration increases and leads to a greater cultural heterogeneity, rethinking and trying out conceptual and practical tools that allow teachers to cooperate with children from diverse homes to - be able to deal with vulnerable and problematic issues - is an important task for teacher education institutions.

In Norway, kindergartens are obliged to develop dialog and understanding with children's homes in order to safeguard children's all-round development [8, 9]. Moreover, kindergarten teacher education institutions are obliged to equip future teachers with professional tools, strategies, and communication capabilities that are applicable in the context of pedagogical work, parental involvement, and collaboration in other instances. Consciousness of ethical dilemmas and power relations involved in work with children and parents is of equal importance [10].

The last Norwegian reform of Kindergarten Teacher Education [10] replaced single scientific subjects/disciplines with interdisciplinary knowledge areas in response to the complexity of the kindergarten institutions. The interdisciplinary character of education was also supposed to make it more profession-oriented and practice-related. According to Hennum \& Østrem [11] the exercise of the kindergarten teacher profession in practice is strongly related to the three following aspects: a) the social/political mandate; b) professional knowledge; and c) ethical and moral responsibilities, included in everyday work situations. The first aspect refers to the kindergarten teacher "corporate responsibility" [12] given to them by the society in form of the steering documents describing the values, goals and tasks of the institution and professionals. The two other aspects refer to the daily situations where the teachers deal with the children, the parents and the personnel, where the teachers are expected to justify their ethical choices and moral responsibilities with their professional knowledge. That's how the kindergarten's social mandate is realized without any procedural control over teacher's daily ethical choices. It's their professional knowledge that shall safeguard their correctness.

As transferring professional knowledge into losing 
ethical dilemmas doesn't happen automatically, the university college where the study was conducted organized an interdisciplinary projects - "The Difficult Conversation" in order to support the students' professional learning at the intersection of knowledge and ethical responsibilities.

"The Difficult Conversation" was intended to address specifically the ethical challenges connected to collaborating with parents in a heterogenic society. Based on the research material of student experiences with the project, we argue that the project provides the students with insights into ethical challenges that await them in the future, and it initiates a reflection process that joins theoretical, ethical, and practical issues. We see such complex reflectivity as more and more necessary among kindergarten teachers to ensure children's well-being in increasingly heterogenic societies.

\section{Norwegian Cultural, Legal, and Institutional Landscape of Child Well-being}

Child well-being is connected to the Nordic cultural value of child-centeredness. This value is expressed by legally safeguarding children's voices and their participation in childcare institutions $[8,13]$ and by considering children's needs when designing institutional practices.

Kindergarten (in Norwegian barnehage) is the central institution in early childhood education responsible for child wellbeing on a daily basis. While participation in this service is not mandatory, $99 \%$ of children aged 0-6 attend kindergartens [14]. Kindergartens should facilitate an inclusive community for all, regardless of the children's backgrounds. When children have special needs or challenges, kindergartens cooperate with other institutions $[9,15]$. Kindergarten teachers are obliged to report any difficulties in areas beyond the competences of kindergartens. The duty of disclosure assumes kindergarten teachers' obligation to formally articulate if he/she suspects that a child is exposed to care deficits or abuse. In most cases, collaboration with other actors demands parental approval, but in cases of abuse certain exceptions are made.

\subsection{Child Welfare Services (Barneverntjenesten)}

Norwegian Child Welfare Service is a socially competent service operating under the Norwegian Directorate for Children, Youth, and Family Affairs. It operates within two main spheres of action: assistance and care. The former refers to mentoring parents and helping to provide economic support, which is often organized as family assistance, mentoring, and home or kindergarten visits. The care sphere refers to removing children from family homes and placing them in temporary foster family care. Children are only removed when sexual abuse or violence is suspected. Children are then removed for periods of six weeks during which suspected abuse or violence are investigated. The Child Welfare Service is, however, encouraged by various parental organizations to focus more on family mentoring. In this work, they expect the greater participation of kindergartens and kindergarten teachers who are in daily contact with children and families [16].

\subsection{Psychological-pedagogical Services (PPT) and Health Care Service}

Psychological-pedagogical services (PPT) is an advisory, expert service operating in each municipality in Norway. Their institutional goals are to advice and mentor both parents and educational institutions (kindergartens and schools) with regard to children/pupils with special educational needs [14]. Kindergartens can, together with parents, apply for an investigation and to have children expertly assessed. However, this requires that staff confer with parents, which can be experienced as difficult. The kindergarten can also apply for anonymous assessments of children's developmental situations at single units.

Another important institution in this picture can, in certain cases, be the health care service (Helsestasjon) where child development and family situations are documented. At the moment, its cooperation with kindergartens is developing, but it is not yet legally regulated, so it varies among municipalities.

\subsection{Pedagogical Tact}

As mentioned above, collaboration with the institutions mentioned above for the sake of child well-being indicates that there is dialog between kindergartens and parents. While parents have to give their permission for the majority of these processes, informing them of sensitive, problematic issues puts them in a vulnerable position. This asymmetrical dialog requires certain professional competences that are embraced in this paper in the concept of the tact of teaching [17], also translated as pedagogical tact [18].

The tact of teaching is a category linked to teacher behavior and it is expressed by kindness and restraint but also with humor and warmth in relation to parents during conferences. It embraces the teacher's responsibility for and attentiveness to creating a secure and open space for their statements and experiences, but it also requires that teachers have the ability to make quick decisions. Furthermore, teachers must use sensitivity and alertness when addressing situations involving strong feelings and emotions. To be tactful means to be able to listen, see, and interpret thoughts, experiences, and feelings through body language in a sympathetic way. Van Manen [17] mentions 
the tact of teaching (pedagogisk takt) as an important aspect of taking the Other's perspective. The daily realities of educators, parents, and childcare specialists are pedagogically conditioned by sensitive insights, active thoughtfulness, and the creative ability to act appropriately and in a caring manner in the immediacy of the moment [18]. Linked to parenting in kindergarten, educational support is given when the kindergarten teacher shows with actions that she/he is involved in what the parent says and that this informs their intentions [17].

This might be done using humor. Humor is a great way to maintain a relaxed, friendly, open, and sympathetic atmosphere between kindergarten teachers and parents. According to van Manen [17: 180] it expresses warmth, empathy, and love.

The article links professional competence and pedagogical tact to understanding and interacting with parents in the kindergarten. The students' professional expertise is developed on the basis of practical knowledge, and is oriented towards the actual practice in which it is conducted. According to Grimen [19] in practice, the competence gets a connection. We want to argue that the students develop their competence through practical designs. The article shows the pedagogical tact as part of the students' professional competence. We understand professional competence as an ethical and intellectual wisdom, where reflection and assessment are important factors in a conversation with parents.

\section{3. "The Difficult Conversation" Interdisciplinary Project}

The interdisciplinary project entitled "The Difficult Conversation" was developed within the knowledge area of SRLE (society, religion, life view, and ethics) that involves pedagogy and knowledge about society, ethics, and religion. The teachers of various subjects began by delivering lectures in which they present knowledge about kindergarten collaboration with other social institutions. During the lecture, the teachers performed a dramatic enactment in which they played kindergarten teachers in dialog with parents from diverse backgrounds in different life situations. Some of the cases presented might be considered to be stereotypical and rich in prejudices and clichés. On the other hand, the authors' professional experiences show that these biased meetings and "solutions" mirror typical, real situations from Norwegian kindergartens. The students' task was to solve these challenges in politically correct, anti-discriminating, tactful, and professional ways. Thus, the students are given specific cases of families and kindergartens and worked on them in teams of three to four people.

Since the cases were presented in very general terms, the students' task was to contextualize them and develop the plot and the characters. They could place their family in deep crisis or in a situation that could be solved in the kindergarten. Since this could have possibly confronted them with certain knowledge gaps in various areas, the teachers provided mentoring. After two days of rehearsals, the students performed their conversations in the classroom. During rehearsals, all of the students were expected to play the role of the kindergarten teacher even though only one of them played this role during the final performance. The students were given 10-15 minutes to perform their projects in front of the whole class and the teachers. Afterward, all the students and teachers provided feedback; however, each performing group was assigned a feedback group that was responsible for making constructive comments on the performance. This often led to discussions on other versions of the plot and alternative solutions.

\section{Project Methodology}

The current research asked about student experiences with the interdisciplinary project of "The Difficult Conversation." The students' experiences were reconstructed using the reflection notes they submitted after the performances. The data consist of 43 reflection notes submitted by student groups in February and November 2015, and January and November 2016, respectively. Twenty-seven of the submitted notes responded to the assignment that was to "describe what was most relevant for you as a future kindergarten teacher." These groups were numbered from 1 to 27 and categorized as REL2015 or REL2016.

Sixteen of them (from November 2016) responded to the following questions: "How do you think the parents experienced the conference?" and "How do you think the kindergarten teacher experienced the conference?" These questions were chosen to facilitate reflections on ethical and professional dilemmas that occurred during the role play, thereby stimulating the students to operationalize their professional identities. For the analysis, the groups were named from 1 to 16 and categorized as PERS2016.

Two examples of the cases that were used, developed, and performed as part of in the project follow below.

Case 1. You are a kindergarten teacher who will have a conference with Trine's mother. Trine is not wearing clean clothes to kindergarten, and they smell of sour milk. Other children have noticed this and have excluded her from play.

Case 2. Aisha, a three-year-old girl, and Bola, a five-year-old boy, are siblings who attend the same unit in the same kindergarten. They live with their parents. The family comes from a non-western country. You observe that Aisha continuously cleans up after her brother in the kindergarten. You wonder how you can respect the parental upbringing mandate while simultaneously realizing your task of promoting gender equal rights and 
equity in the kindergarten.

However, the students were allowed to contextualize the given cases into more or less serious, critical, or controversial contexts. The reflection notes gathered after the performances created 83 pages of research material. Students granted permission for us to use all of their work in the research project. The reflection notes that were submitted after the performances were written in the same groups that were performing the cases. That means that the written reflections address the collective dimension of the experience and dilemmas shared by the student teams, which refers to the joint character of professional competence.

Since our goal was to understand the students' perceptions and reflections, the research material was analyzed with the phenomenological analytical approach [20]. This means that the material was analyzed from the bottom-up. The codes were generated from the data and not from pre-existing theories. Theoretical concepts, for example, the tact of teaching, appeared at the second level of analysis when we tried to identify the existing theoretical concepts for the codes developed during the analysis. We tried to work as closely to the students' reflections as possible. At the same time, we sought awareness of our own pre-understandings and prejudices that shape the interpretative process. These were not surprising within the phenomenological hermeneutic framework, but we realized that being teachers in the project placed us in a particular position that was both vulnerable and powerful.

As teachers researching students' reflections of our own practice, we were performing research within our own "culture," while a great part of our cultural knowledge was silent and unconscious [21]. On the other hand, the insider perspective provided us with access to various dimensions and knowledge that, again, allowed us to understand and contextualize diverse meanings and practices and interpret them in relation to other meanings and practices [22].

We read the texts together to clarify our position of understanding. These were close readings during which the texts were read and discussed many times while focusing on different codes $[20,23]$. We identified the following themes that occurred frequently in the students' texts, and thus suggested how the students perceived the project. These included statements such as "we liked this project," "demanding, but educational," "interesting to watch the other groups performing," "challenging to take others' perspectives". These were matched to the parts of the texts that related to them (coding). Afterward, we interpreted each theme in depth [24]. Questions that drove this part of our analytical work were: How can we understand this? What kind of meaning is there an attempt to communicate here? How can we interpret it? This allowed us to group some of the themes together to develop new ones, all in order to develop the final categories [25]. These categories are named in the Results section below. Reading and interpreting in a team of three teachers was supposed to objectivize, or rather inter-subjectivize, the reconstructed understandings.

The significant limitations of the study were related to our involvement in the field and the student groups. We knew the students and had established relationships with them, which might have influenced them allowing us to use the reflection notes as research material. Even though the students could refuse to participate in the research project, none did. We received only positive feedback about the research, which raised questions concerning hidden coercion to participate in the study. Moreover, since the reflection notes functioned as an assignment within the project, the responses submitted might have been more loyal and correct than if they had not been assessed. The final categories developed in the analysis were as follows:

- "We want more of this work method;"

- "It was a demanding process;"

- "It was challenging to take the parents' perspective;"

- Diversity in kindergarten;

- $\quad$ Learning from and with each other;

- Pedagogical tact in parental collaboration;

- Critical perspective on "The Difficult Conversation."

\section{Results}

\section{1. "We want more of This Work Method"}

The student utterances gathered in this final category claimed that the students wanted more of this kind of teaching and learning in more knowledge areas. They experienced it as motivating and exciting. It provided the students with opportunities to gain and articulate knowledge in another manner that they found interesting and helpful for learning. "There was less focus on reading in this way than we do in preparation for classes or cramming for exams and the performance was also different, in a way better and more real" [Group16_REL2015]. The students emphasized the relevance of this working method for the conditions of kindergarten teacher work. "It is great to see theory done in practice" [Group1_REL2015]. This corresponded with earlier research showing that active learning helps students to realize dialectic relationships between theory and practice and develop competence to act $[17,18]$. This competence to act is not neutral, but it implies ethical reflections on ethical dilemmas. Moreover, it seems to motivate them to test all their knowledge when faced with new experiences and insights [26]. This is how the need for new knowledge and new skills becomes apparent and motivates them for further learning [26: 171].

\section{2. "It Was a Demanding Process"}

The students perceived both the process of preparation 
and performance as demanding in "The Difficult Conversation" project. When looking deeper into students' responses, we came to understand that the adjective "demanding" referred to another matter of dealing with the required reading so that they could solve real-life problems.

This demanded reading not only to know or to become informed, but also to act, react, and convince. This prompted students to discuss theoretical facts in reference to their practical knowledge. In this context, they reported that "our own experiences were as important as the required reading" [Group_24_REL2015]. However, the professional theoretical knowledge was seen as basic- - it was the required reading that conditioned success in the role play" [Group_12_REL2016]. The project demanded that the students had a high degree of complex theoretical knowledge. In the case described below, the student group had to combine knowledge about language development [27] with legal guidelines for psychological diagnoses. They needed to read on how parents from specific social backgrounds perceive recommendations for submitting their children to diagnostic procedures [28]. Moreover, they gathered this knowledge to apply it during the conversation with the parents in which they wished to recognize both the parents' and their own meanings, but also to convince the parents to allow the child to undergo the diagnostic process. An excerpt from a reflection note illustrates this demanding complexity.

Our case addresses Marcus who we wanted to send on to PPT because of his language development. His parents are professors, and they have previously denied that the child could have any developmental difficulties connected to language. This forced us to look for a linguistic developmental problem that could easily be rejected, that is to say, one that was not so bad or serious. The other challenge was to convince them about the diagnostic procedure this time. In order to this, we reflected on what made the parents reject this procedure previously. This was something we discussed a lot [Group_16_REL2015].

Other utterances gathered in this category perceived that the performance was demanding. Nevertheless, the role play presented by the academic teachers was helpful.

The teachers' role play also presented a parenting conversation in which the parents had separated and the child had responded to it in the kindergarten. It was interesting to see the role play, and we thought it was helpful when we continued working on the case. [Group 7 REL 2015].

Other teachers' actions that were seen by the students as helpful and those that facilitated the demanding process included mentoring in groups, availability for conversations and advice, but also lecturing (using drama role play). Many student groups wrote that they would like to have more lectures in relevant areas before the roleplay project began.

\section{3. "It Was Challenging to Take the Parents' Perspective"}

The core idea of the project was to provide students with an opportunity to experience the same situation from different perspectives (parent, teacher, external services), to assume the roles of the various actors, and to assess what one would have done if one had been involved [26]. Van Manen [17] claims that the tact of teaching is an important aspect of taking the Other's perspective. When collaborating with children's parents, the tact of teaching becomes the teacher's ability to show through actions that she/he understands, respects, and is following what the parents say. "The Difficult Conservation" trains students in this by having them play the parents and experience the parental perspective. However, taking the perspective of the parents was not always easy for the students.

There are many different types of families in today's society, and during the project we have seen examples of many of them. This diversity makes the project very interesting and varied with a wide field of engagement. In our performance we played two gay parents. We had to imagine how these parents thought. It was challenging to take the parents' perspective [Group18-REL, 2015].

The given task helped the students to practice expressing empathy and sympathy for other people's difficult situations. In order words, the students practiced caring and awareness, and attempted to develop a deep understanding of other people's thoughts, experiences, feelings, and body language $[17,18]$.

According to Levinas \& Aarnes [29], empathy is about the ability to acknowledge that the other has boundaries. This implies humility for something else, something that we cannot understand. This creates an ethical obligation to recognize the other as genuinely different from one's self. In the case of the students, this was about the acceptance of the impossibility of fully understanding the parents. This led to another challenge that was about being aware of one's own thoughts and attitudes about parents. These reflections contributed to the development of the tact of teaching $[17,18]$. We also consider this as developing the students' professional competence.

\subsection{Diversity in Kindergarten}

Some of the groups experienced challenges in relation to the multi/intercultural perspective. "Our case was about the siblings Aisha and Bola, in which Aisha was constantly cleaning up after Bola. We were going to prepare a conversation with the parents" [Group_2_REL2015]. 
The students referred to a note on equal rights included in the Framework Plan for Kindergarten [9] and wrote afterwards that "In this case, taking into consideration parental values wasn't possible. They violated the values of equity and equality in [Norwegian] society" [Group_2_REL2015].

It was a problematic conclusion that was surprising, but since this form of teaching does not impose any specific solutions, it was possible.

The case of Aisha and Bola was the one that generated a high level of involvement and discussion, so we, as teachers, succeeded in activating and challenging attitudes about various ethical issues in practice [26]. At the same time, the case-based teaching and learning did not provide specific instructions on how to handle complex cases. Rather, the goal was to increase awareness and stimulate reflection, especially in contexts where there was no solution, but rather a dilemma [26]. Our goal was to pursue the category of cultural sensitivity understood as various culture-rooted preferences at the level of values, lifestyles, forms of communication, and characteristics of children [30]. In the kindergarten teacher profession, it is of great importance to present an open approach when meeting with families that challenge the teachers' own attitudes and values, as well as the values imposed on the kindergarten by the steering documents. When finding $\mathrm{him} / \mathrm{herself}$ in such ethical dilemmas, kindergarten teachers have to rely on their professional knowledge and use it as a base for professional judgments. Implementing cultural sensitivity into the kindergarten practice includes a great amount of professional judgments in daily practice. Our intention was to give the students a little taste of this intensity of ethical choices in the kindergarten setting.

Another group "learned that the educational leader has to behave professionally towards parents regardless of the context or situation that occurs" [Group 21 REL2015]. They worked on a case in which a Muslim father refused to shake hands with the female educational leader; she overlooked it and continued the conversation. The students learned that collaboration is more challenging and vulnerable when the educational institution and parents present different values. Knowledge about cultural variations can increase teachers' empathy and thereby safeguard collaboration sensitively [17].

\subsection{Different Dimensions of Learning}

Almost all the reflection notes emphasized a major learning outcome from the project. In our analysis we found that the notes visualized learning outcomes in different elements in the project:

Body language, mentoring, parental conference, to watch others role play, feedback for and from other groups, introduction lectures, the importance of cooperation within groups, and the meaning of being well prepared. "We learned that we have to be more aware of our body language when meeting parents, so we practiced a lot with facial and body expressions and gave feedback to each other" [Group_13_REL2016]. Several other groups pointed out that during the days when the focus was on "The Difficult Conversation," they gained a greater understanding of the importance of knowledge and professionalism in meetings in the home and especially in difficult situations and conversations.

The work process and the learning outcomes of this project helped to strengthen the student's professional competence, as we see it. An important part of this was when the groups were responsible for responding to each other's progress. Each group had an assigned group that provided constructive feedback. When we consider the socio-cultural learning perspective, we see knowledge as situational; that is, we understand it as situational and context-dependent. Knowledge is created in collaboration with others, and, therefore, it is to be regarded as a socio-cultural phenomenon [31, 32]. Experiences of receiving feedback on one's own performance can increase the level of reflection and provide security and courage in learning from feedback [33]. In the case of the professional education program, it facilitates qualification process for professional life.

We think the day in which we had the performances was very educational. It was a good arena for reflection, it was nice to observe the other groups, and the feedback we received was useful. In particular, we liked that we had to evaluate each other's performances. It was also nice that it was open for discussion and everyone could come up with input. One learns a lot from a good discussion and hearing other people's points of view and thoughts [Group 15, REL 2015].

Several groups pointed out that guidance from the teachers was very educational. It helped the students to become aware of their own pre-understandings and prejudices, especially in relation to families from minority backgrounds. When discussing the case of a mother giving the child a stern look, the students pointed at the possibility of domestic violence and a need to inform child welfare services. After guidance from teachers, the students were able to consider the episode as the effect of a bad day at work, being stressed, and not necessarily a symptom of violence in the family that needed to be reported.

The will to unmask what lies under our prejudices and biases, for example against families from minority backgrounds, is necessary to achieve optimal solutions when communicating with parents [34]. This is about becoming conscious of one's own understanding and tending to categorize those that are different, and about reflecting on how one would interpret things in a similar collaborative situation if the parents were ethnic Norwegian. 


\subsection{Pedagogical Tact in Parental Collaboration}

The tact of teaching performed in the context of a conference with parents is operationalized in relation to the following aspects: showing care for the child, preparing parents for the next stage of the meeting, active listening, giving/supporting voice, and balancing emotions [35]. When staff and parents work closely together over time, they become better known to one another, both in the professional context, but also in many cases in the private sphere. Professionals should reflect on how they engage in relationships with parents and how to balance the professional and private levels. According to Skau [36], it is a professional act of leadership ability to distinguish and understand one's own role in terms of what is personal, impersonal, private, and public. This turned out to be difficult for the students.

We found it difficult to know how it was okay to be and what we should not interfere with. Here it was important that we, as educators, behaved in a respectful manner, while emphasizing the importance of the parents collaborating without entering their privacy too much [17, REL 2015].

However, being tactful in relation to showing care for children and preparing parents for the next stage of the meeting was experienced as less challenging.

We started by saying something positive about the child. We wanted to make it clear that we see the whole child before we addressed the difficult issues. It is important that the educational leader shows that she/he cares about the child. After that it was possible to discuss the problem as long as the mother took it with respect. The teacher was pedagogic in the way that she prepared the parents for the negative stage, so that they did not feel interrupted or rejected. As parents, we experienced the teacher actively listening, which facilitated good communication [Group_4_REL2015].

This shows an understanding of the need to see and interpret parental reactions so that the message can be communicated correctly. This group managed to convey something negative in a respectful way. Moreover, they took great care in concluding "The Difficult Conversation" with regard to the parents' emotional state. According to van Manen [17] the tact of teaching is about placing the parents and their experiences and perceptions of the meeting and the message at the center of the conversation.

The aspects of giving/supporting voice were visible in another empirical example. "We have the case of a divorced couple whose daughter smelled bad in kindergarten" [Group 22 REL 2015]. The students understood that their task was to put themselves in the parents' position and experience their situation so they could handle it tactfully $[17,18]$. That tact of teaching led them to focus on the mother's body language and her reactions, which, again, supported her to "tell the father that she was depressed, which was something the father did not know" [Group 2 PERS 2016]. The educational leader understood from the mothers' body language that it was difficult for her to talk about it. The teacher was tender and acknowledging when supporting the mother. The same group pointed out that not having a script for such a conversation gave them more space to focus their attention on the parents and their real "voices" [17]. Focusing on and expressing sympathy for the parents must not, however, direct the main focus away from the child. Balancing these issues may be challenging, but this is also a part of professional competence.

For the kindergarten employees it was important to keep the focus on Trine (the child), while the parents talked rather more about their own problems. (...)It was an effort to keep the focus on myself as a professional practitioner and Trine, who could have easily disappeared from the conversation [Group 2 PERS 2016].

In this case, the students experienced well-known, in-service challenges and dilemmas regarding maintaining a balance between being attentive and understanding, and controlling the focus of the conversation without appearing to be dismissive or invasive.

\subsection{Critical Perspective on "The Difficult Conversation"}

The critical remarks in the students' notes referred to organization, logistics, and miscommunication among teachers, access to interdisciplinary, and not only disciplinary, knowledge, proportions between theoretical and practical knowledge, the number of critical comments, and their own thinking processes.

The project was interdisciplinary, which required collaboration in areas representing different disciplines. For logistical reasons, it was not always possible to have all the necessary meetings to ensure the teachers had a common understanding of the tasks. This was reflected in students receiving different information from different teachers involved in "The Difficult Conversation." Another factor was that the project was new, so we did not have any established routines, which led, in some cases, to us communicating our individual (various) suppositions to the students.

Tips for you teachers for next time include talking together and agreeing on an array of practical things in advance, because different groups received different messages on how they could do things, such as whether it was permissible to have scripts or not and how long the presentations should last. [Group_5_REL2015].

The organizational challenges spotted by the students referred to the vulnerability of the project content and the task in confrontation with the logistics of daily campus life [26: 182]. The students indicated there were problems 
finding time for group-meetings, booking rooms, and attending other lectures that were held at the same time. This type of learning requires time and engagement. According to the students, it was important to be relieved of other subjects/lectures in order to benefit from the project fully.

The next criticism referred to access to all the teachers representing different subjects during mentoring. "All the teachers should have mentored all the groups so that all students could have received guidance on all subjects and their perspectives in the cases." [Group_4 REL 2015

The students' desire for interdisciplinary knowledge was seen by the teachers as a very positive sign in their professional development. Even though the students wanted more interdisciplinary knowledge, their notes differed in the perception of the proportion between theoretical and practical knowledge, with some wanting more theory, while others wanted less. "There was too much of the heavy [theoretical] stuff before rehearsal" [Group_19_REL2015], said some students, while others thought that they "would have liked the project to last longer (...) and we would also have liked to learn more theory and have had more lectures on this topic" [Group_22_REL2015]. Chen and Martin [37] point out the need for a strong knowledge base attributed to different teaching strategies in advance of role play, which is what formed our plan for the project.

Another aspect of the project that received critical comment was the lack of critical feedback. The students experienced the feedback they received as focusing too much on the good aspects of their projects. "It would have been ok to provide feedback on how to improve the conversation as a kindergarten teacher and not just that focused on what was good about the conversation" [Group_4_REL2015]. This opinion corresponded with our experiences, as teachers, of the assessment part and prompted the development of more formative assessments.

Another aspect pointed out by the students referred to the creation of a reflection room at the end of the project. This reflection room could be, according to the students, created by giving everybody open access to all the reflection notes.

We want to learn more, so it would also be natural for a process in which we, as students, either participated in a joint reflection session in plenary or that we reviewed and shared all written reflection notes. This would make the experience even more educational. Thus, we could have access to the silent knowledge that often only remains written and is not presented orally in front the whole class. [Group 3_REL_2015].

The last area of critical remarks addressed a different matter and was directed at the students' own thinking and the first, in some cases sided solutions they came up with.

During our discussion, we were very unsure how to solve the case. Should we contact the child welfare services or not? We did not perceive that the pedagogical leader had very good contact with the parents (...). In the conversation, the mother said that she had slapped Henrik several times without thinking about it. During our conversation after the role play, we decided to contact the child welfare service (...). In retrospect, we would have resolved the matter a bit differently. We would have contacted child welfare but still tried to do everything we could to help the mother [Group _ 4 _ REL 2015].

The fact that "The Difficult Conversation" prompted students' ethical reflections on their own motives, actions, and decisions showed how the project contributed to student professional judgment competence. It also contributed by making them aware of the ethical intensity of teaching, caring, and parental collaboration - and of the fact that dilemmas are never "finally solved". Last but not least, they could understand that being professional teachers means accepting being and working with all these dilemmas without ever having concrete answers that are always right. Many of the students' notes discussed other possibilities for the solutions that they decided on in "The Difficult Conversation." We interpret this as evidence that the students were entering on the professional path in which ethical reflection is a crucial element.

\section{Summary}

Based on the experiences presented, we argue that the interdisciplinary project of "The Difficult Conversation" contributed much to the development of reflectivity that grows at the intersection of theory, ethics, and practice. In other words, it contributed to the development of knowledge and skills that allowed students to operate at the intersection of professional knowledge and ethics and thereby realize the kindergarten social mandate [11]. Some aspects of the project that were experienced, such as the articulation of professional knowledge in uncomfortable social settings, collective reflection on the limits of one's own thinking, assuming the perspective of the Other, and attempting to perform tactful actions - are seen by us as fundamentally connected to professional competence.

The first aspect experienced, that of articulating professional knowledge, is of great importance. A well-developed facility with the language represents professionalization in daily work. The kindergarten teacher can visualize her/his knowledge through language actions. However, in Norwegian kindergartens teachers often downplay and limit their use of professional language in order to be understood by their coworkers and assistants. Students who train to speak about education, values, and an understanding of the realities conveyed by it can gain more awareness about themselves and their 
own professional socialization [38: 313].

The aspect of collective reflection seems to be one of the results of the role play performed in the project. Chen and Martin [37] identify role playing as a method that facilitates attempts to reach various unconventional solutions that promote reflexive processes. Reflection helps participants to investigate their feelings and thoughts and prompts them to ask themselves why they felt or behaved in a particular way [37: 98]. Moreover, role playing stimulated them to reflect on their own values and even biases. Thus, this exercise underlined the importance of this type of learning in their professional development.

The students reported that the experience of assuming the Other's perspective was difficult but educational. The students were challenged to develop and to express care, empathy, responsiveness, and patience. We saw these as crucial elements of the tact of teaching that is important for growth. In parental collaboration, it is necessary for pedagogues to assume a responsive, attentive role in creating a secure and open space for parents' statements and experiences [17: 135]. Increasing diversity among children and their families demands that teachers develop new competences. Professional competence and the tact of teaching are important aspects of it [39] as is the cultural sensitivity that the students reported having experienced and learned.

Our conclusions address the practice of kindergarten teacher education, and we propose there is a need to rethink the teaching methods and to limit Power-Point presentations in order to better form professional competences to act and prepare students for the challenges of contemporary kindergartens. Developing and evaluating interdisciplinary teaching methods and institutional practices in the kindergarten teacher education program, that respond to the societal challenges - is an important topic that requires future research.

\section{REFERENCES}

[1] European Council Conclusions. Council Conclusions on the Education of Children with a Migrant Background (OJ 2009/C01/07). Official Journal of the European Union C301/5. 2009. Online available from: https://eur-lex.europa.eu/LexUriServ/LexUriServ.do?uri= OJ:C:2009:301:0005:0008:EN:PDF

[2] European Commission Decision 2018, Horizon 2020 Work Programme 2018-2020. 13. Europe in a changing world Inclusive, innovative and reflective societies European Commission Decision C (2018)4708 of 24 July 2018. Online available

from:https://ec.europa.eu/research/participants/data/ref/h20 20/wp/2018-2020/main/h2020-wp1820-societies_en.pdf

[3] Ministry of Children, Equality and Inclusion. En helhetlig integreringspolitikk [A holistic integration policy].
Ministry of Children, Equality and Inclusion. Oslo. 2012-2013.

[4] P. Mikiewicz, A. Sadownik. Szczęśliwy traf: edukacja w procesie adaptacji migrantów z Polski w Wielkiej Brytanii, Wydawnictwo Dolnoslaskiej Szkoly Wyzszej. Wroclaw. 2014.

[5] P. Mikiewicz, M. Jurczak-Morris, A.R. Sadownik, Rola systemu edukacji $\mathrm{w}$ procesach adaptacji migrantów do struktury społecznej. Rozważania na bazie założeń dotyczących alokacyjnej funkcji systemu szkolnego. Rocznik Lubuski, Volum 1. (44), 109-126, 2018.

[6] SIRIUS Network Policy Brief Series, Issue no 7: Developing school capacity for diversity. By: S. Severiens. 2014. Online available

from:http://www.sirius-migrationeducation.org/wp-content /uploads/2018/10/Policy-Brief-3_School-Capacity.pdf

[7] SIRIUS Network Policy Brief Series, Issue no 7: Refugee children in education in Europe. How to prevent a lost generation? By M. Crul.http://www.sirius-migrationeducat ion.org/wp-content/uploads/2018/10/Refugee-children-in-e ducation-in-Europe.-How-to-prevent-a-lost-generation.pdf

[8] Kindergarten Act No. 64 of June 2005 relating to kindergartens. Enacted 1. January 2006. Online available from:

https://www.regjeringen.no/globalassets/upload/kd/vedleg g/barnehager/engelsk/act no_64 of june 2005 web.pdf

[9] Norwegian Directorate of Education and Training. Framework Plan for Kindergartens: Contents and Tasks. 2017. Online available

from:https://www.udir.no/globalassets/filer/barnehage/ram meplan/framework-plan-for-kindergartens2-2017.pdf

[10] Norwegian Ministry of Education and Research. Nasjonale retningslinjer for barnehagelærerutdanningen. Oslo, 2012. Online available

from:https://www.uhr.no/_f/p1/i8dd41933-bff1-433c-a82c $-2110165 \mathrm{de} 29 \mathrm{~d} /$ blu-nasjonale-retningslinjer-ferdig-godkje nt.pdf

[11] B.A. Hennum, S. Østrem. Barnehagelæreren som profesjonsutøver. Cappelen Damm Akademisk. Oslo. 2016.

[12] L.T. Grindheim. Kva skal den profesjonelle barnehagelæreren bruke tid til? In: L.T. Grindheim, T. Kruger, P.E. Leirhaug, D. Wilson (Eds.). Lærerprofesjonalitet i utdanningspraksiser. Fagbokforlaget. Bergen. 2016.

[13] The Child Welfare Act. Act of 17 July 1992 No. 100 relating to Child Welfare Services (the Child Welfare Act As subsequently amended, most recently by Act of 21 June 2013 No. 63). 2013. Online available at: https://www.regjeringen.no/contentassets/049114cce0254e 56b7017637e04ddf88/the-norwegian-child-welfare-act.pdf

[14] Directorate of Education. Utdanningspeilet - Tall og analyse av barnehager og gruppeopplæring I Norge. Oslo. 2016. Online available from: http://utdanningspeilet.udir.n o/2016/

[15] Directorate of Education. Kompetanse i barneahgen. Strategiplan for kompetanseutvikling I barnehagesektoren 2007-2010. Oslo. 2007. 
[16] A. Sagbakken, B. Andeaa. Barnevern i barnehagen. En felles utfordring. Kommuneforlag. Oslo. 2007.

[17] M. van Manen. Pedagogisk takt. Betydningen av pedagogisk omtenksomhet. Caspar Forlag. Oslo. 1993.

[18] M. van Manen. Pedagogical tact: Knowing what to do when you don't know what to do. Routledge. London - New York. 2016.

[19] H. Grimen. Profesjon og kunnskap. I: A. Molander, L.I. Terum(eds). Profesjonsstudier, Universitetsforlaget. Oslo. 2008.

[20] J.A. Smith, P. Flowers, M. Larkin. Interpretative phenomenological analysis: theory, method and research. SAGE. Thousand Oaks. 2009.

[21] Wadel, C. Feltarbeid i egen kultur, Cappelen Damm Akademisk. Oslo. 2014

[22] S. L. Howell. Feltarbeid i vår egen bakgård: noen refleksjoner rundt nye tendenser i norsk antropologi. Norsk Antropologisk Tidsskrift, 12(1-2). 2001.

[23] A. Johansson. Narrativ teori och metod: med livsberättelsen i fokus. Studentlitteratur. Lund. 2005.

[24] T. Thagaard. Systematikk og innlevelse: en innføring av kvalitativ metode. Fagbokforlaget. Bergen. 2009.

[25] E. Brun, N. Carson. Medstudentveiledning i et profesjonsperspektiv. I: E.E. Ødegaard, M.S. Øklnad (Eds.) Fortellinger fra praksis - trøbbel, vendepunkt og stolthet. Fagbokforlaget, 153-173. 2015.

[26] K.H. Lycke. Problembasert læring, caseundervisning og prosjektarbeid. In: H.I. Strømsø, K.H. Lycke, P. Lauvås. Når læring er det viktigste. Undervisning i høyere utdanning. Cappelen Damm akademisk. Oslo. 2016.

[27] A. Høigård, Barns språkutvikling - muntlig og skriftlig, Universitetsforlaget. Oslo. 2013.

[28] M. B. Drugli, R. Onsøien. Vanskelige foreldresamtaler gode dialoger. Cappelen Akademisk Forlag. Oslo. 2010.

[29] E. Lévinas, A. Aarnes. Den annens humanisme. Aschehoug i samarbeid med Fondet for Thorleif Dahls kulturbibliotek og Det norske akademi for sprog og litteratur. Oslo. 2004

[30] Y. Bakken. Kræsjkurs i flerkulturell kompetanse - bra å vite for et godt samarbeid mellom barnehage og hjem. In: Y. Bakken, V. Solbue (Eds.) Mangfold i barnehagen. Fra politisk vilje til flerkulturell virkelighet? Fagbokforlaget. Bergen. 2016.

[31] M. Hedeegaard. Institutional practice, cultural positions, and personal motives: Immigrant Turkish parents' conception about their children's school life. In: S. Chaiklin, M. Hedegaard \& U.J. Jensen, (Eds.) Activity theory and social practice, Aarhus University Press, Aarhus. 1999

[32] M. Hedegaard. Strategies for Dealing with Conflicts in value Positions between Home and School: Influences on Ethnic Minority Student's Development of Motives and Identity, Culture \& Psychology, Vol.11, No.2, 187-205, 2005.

[33] G. S: Meyer, I. Reigstad. Transformative learning theory. In:
J. Mezirow, E. Taylor (Eds). Transformative learning in practice, 18-32. CA:jossey-Bass. San Francisco. 2009.

[34] V. Solbue. Hvordan utvikle et kritisk blikk på egne fordommer ved bruk av krtisik venn i kollegaveiledning. In: V. Solbue, Y, Bakken (Eds.) Mangfold i skolen. Frå politisk vilje til flerkulturell virkelighet? Fagbokforlaget. Bergen.

[35] A.L.L. Schibbye. Relasjoner: et dialektisk perspektiv på eksistensiell og psykodynamisk psykoterapi. Universitetsforlaget. Oslo. 2012.

[36] G.M. Skau. Gode folk vokser. Personlig kompetanse i arbeid med mennesker. Cappelen Damm Akademisk. Oslo. 2017.

[37] J. C. Chen, A.R. Martin. Role-Play Simulations as a Transformative Methodology in Environmental Education. Journal of Transformative Education Vol 13 (1). 2015.

[38] M.V. Larsen, A.K. Slåtten. En bok om oppvekst. Samfunnsfag for barnehagelærere. Fagbokforlag. Bergen. 2015.

[39] A. Sadownik, E. E. Ødegaard. Early Childhood Education and Care in Norway: Cultural Historical Context, New Regulations and Perceived Quality. In: Early Childhood Education in the 21st Century - Volume 1. New York, Routledge. 2018. 